\title{
Analisis Keterampilan Berpikir Tingkat Tinggi Siswa dalam Pemecahan Masalah Matematika Berdasarkan Taksonomi Anderson
}

\author{
Abdul Rahman ${ }^{1}$, Asdar $^{1}$, dan Nur Indah Surahman ${ }^{1, \text { a) }}$ \\ ${ }^{1}$ Jurusan Matematika, Fakultas Matematika dan Ilmu Pengetahuan Alam, Universitas Negeri \\ Makasssar, 90224 \\ a)nurindahsurahman@gmail.com
}

\begin{abstract}
Abstrak. Penelitian ini termasuk jenis penelitian kualitatif yang bertujuan untuk mengetahui deskripsi hasil analisis keterampilan berpikir tingkat tinggi siswa dalam pemecahan masalah matematika berdasarkan taksonomi Anderson. Pendeskripsian diperoleh melalui analisis hasil tes keterampilan berpikir tingkat tinggi siswa dalam pemecahan masalah matematika. Deskripsi tersebut juga didukung oleh data hasil wawancara setelah tes dilaksanakan. Uji keabsahan data menggunakan triangulasi waktu yaitu dengan melakukan wawancara untuk mencari kesesuaian data yang bersumber dari masalah yang sama pada waktu yang berbeda. Teknik analisis data menggunakan langkah-langkah analisis data menurut Miles dan Hubberman.Penelitian ini dilaksanakan di SMA Negeri 1 Mamuju dengan jumlah subjek sebanyak 2 orang yang dipilih menggunakan teknik purposive sampling. Hasil penelitian menunjukkan bahwa: (1)keterampilan berpikir tingkat tinggi siswa yang mengikuti bimbingan OSN Matematika dalam pemecahan masalah matematika berdasarkan taksonomi Anderson kategori menganalisis(C4) melibatkan keterampilan dalam memahami(C2) dan mengaplikasi(C3); kategori mengevaluasi(C5) melibatkan keterampilan dalam memahami(C2), mengaplikasi(C3) dan menganalisis(C4); sedangkan kategori mencipta(C5) melibatkan keterampilan dalam menganalisis(C4), (2)keterampilan berpikir tingkat tinggi siswa yang tidak mengikuti bimbingan OSN Matematika dalam pemecahan masalah berdasarkan taksonomi Anderson kategori menganalisis(C4), yaitu tidak mampu menganalisis dengan baik karena tidak mampu memahami(C2) sehingga salah dalam menginterpretasi(C3); kategori mengevaluasi(C5) melibatkan keterampilan dalam memahami(C2) dan menganalisis(C4); sedangkan kategori mencipta tidak dapat diidentifikasi.
\end{abstract}

Kata Kunci: Berpikir Tingkat Tinggi, Pemecahan Masalah, Taksonomi Anderson.

\begin{abstract}
This study is a qualitative study that aims to investigate description of analysis results the students' higher order thinking skill in mathematics problem solving based on Anderson taxonomy. The descriptions were obtained by analysis the test results of students' higher order thinking skill in mathematics problem solving. The description is also supported by interview data after the test was conducted. Data validation technique using time triangulation is by conducting interviews to find the suitability of data sourced from the same problem at different times. Data analysis technique using data analysis steps according to Miles and Hubberman. This study conducted in SMAN 1 Mamuju with the number of subjects are 2 people that selected using by purposive sampling technique. The results of the study indicate that: (1)students' higher order thinking skills who follow guidance of OSN Mathematics in mathematics problem solving based on Anderson's taxonomy in analyzing category(C4) involving skills in understanding $(C 2)$ and applying(C3); evaluate category(C5) involving skills in understanding $(C 2)$, applying(C3) and analyzing(C4); while the creating category(C5) involving skill in analyzing (C4), (2) students' higher order thinking of students who don't follow guidance of OSN Mathematics in mathematics problem solving towards on Anderson's taxonomy in analyzing category(C4), that is not able to analyzing well because not able to understanding(C2) so mistaken in interpretation(C3); evaluating category(C5) involving skills in understanding(C2) and analyzing(C4); while creating category can't be identified.
\end{abstract}

Keywords: Higher Order Thinking, Problem Solving, Anderson's Taxonomy 


\section{PENDAHULUAN}

Keterampilan berpikir adalah kecakapan dalam menggabungkan sikap-sikap, pengetahuan, serta keterampilan-keterampilan yang memungkinkan seseorang dapat membentuk lingkungan yang efektif (Anjarsari, 2014). Kecakapan memiliki arti kemampuan dalam melakukan sesuatu secara cepat dan benar. Soemarjadi, Muzni, \& Wikdati (1991) menyetakan bahwa seseorang yang melakukan sesuatu dengan cepat tapi salah tidak dikatakan terampil, begitu pula sebaliknya. Jadi, keterampilan berpikir dapat diartikan sebagai kemampuan mengembangkan pengetahuan atau ide secara cepat dan tepat dengan menghubungkan bagian-bagian pengetahuan sehingga menghasilkan kesimpulan yang efektif.

Tingkat keterampilan berpikir dapat diklasifikasikan ke dalam enam tingkatan, yaitu mengingat (C1), memahami (C2), mengaplikasi (C3), menganalisis (C4), mengevaluasi (C5), hingga mencipta (C6). Keterampilan berpikir tingkat rendah terdiri atas keterampilan dalam hal mengingat, memahami, dan mengaplikasi. Sedangkan, keterampilan berpikir tingkat tinggi terdiri atas keterampilan dalam hal menganalis, mengevaluasi, dan mencipta (Anderson \& Krathwohl, 2001).

Keterampilan berpikir tingkat tinggi merupakan bagian dari keterampilan berpikir yang penting untuk dikembangkan seseorang termasuk siswa (Apino \& Retnawati, 2017). Keterampilan berpikir tingkat tinggi juga diartikan sebagai kemampuan dalam menghubungkan, memanipulasi dan mentransformasi pengetahuannya untuk memecahkan masalah dalam berbagai situasi (Rofiah, Aminah \& Ekawati, 2013). Dengan begitu siswa dengan tingkat keterampilan berpikir tinggi lebih muda dalam menyelesaikan berbagai masalah dalam situasi kompleks dan tidak rutin. Salah satu cara untuk mengembangkannya yaitu melalui kegiatan pemecahan masalah (Abosalem, 2016).

Kegiatan pemecahan masalah dapat diwujudkan melalui beberapa program ekstrakurikuler di sekolah. SMA Negeri 1 Mamuju merupakan salah satu sekolah yang mengadakan bimbingan khusus bagi siswa yang memiliki bakat maupun minat untuk mengembangkan keterampilan yang dimilikinya. Ekstrakurikuler tersebut berupa pengembangan minat dan bakat siswa dalam bidang seni, olahraga, dan sains.

Ekstrakurikuler dalam bidang sains mencakup pelatihan bagi para siswa yang akan mengikuti Olimpiade Sains Nasional (OSN). Pada kegiatan tersebut para siswa dibiasakan untuk menghadapi masalah matematika yang memerlukan kemampuan dalam memanfaatkan pengetahuan dasarnya untuk menyelesaikan masalah matematika yang tergolong kompleks. Pembiasaan siswa dalam menyelesaikan masalah yang kompleks menunjukkan adanya potensi keterampilan berpikir tingkat tinggi.

Potensi keterampilan berpikir tingkat tinggi siswa ini juga dapat dilihat melalui nilai akademisnya. Zohar (2003) menyatakan bahwa siswa dengan nilai akademis tinggi juga memiliki skor tinggi dalam keterampilan berpikir tingkat tinggi (Ardiana \& Sudarmin, 2015). Berdasarkan keterangan dari salah satu guru mata pelajaran matematika, siswa yang mengikuti ekstrakurikuler bidang sains matematika memiliki nilai akademis yang cukup tinggi untuk mata pelajaran matematika.

Untuk mengetahui lebih lanjut mengenai keterampilan berpikir tingkat tinggi siswa dapat dilakukan melalui pengamatan respon siswa dalam aktivitas menyelesaikan masalah (Swartz \& McGuiness, 2014). Masalah yang membutuhkan ketiga aspek keterampilan berpikir tingkat tinggi dapat mengeksplorasi keterampilan berpikir tingkat tinggi yang dimiliki siswa. Masalah dapat dikembangkan melalui beberapa kompetensi atau materi matematika yang cukup rumit bagi siswa. Salah satu kompetensi matematika yang membutuhkan keterampilan berpikir tinggi yaitu kompetensi dalam aspek aljabar dan geometri. 
Ariani (2014) dalam penelitiannya yang berkaitan dengan keterampilan berpikir dalam menyelesaikan soal eksponen dan logaritma sebagai salah satu materi aljabar, menemukan bahwa kebanyakan siswa masih kesulitan dalam menyelesaikan masalah pada materi tersebut.

Utamanya pada aspek keterampilan berpikir tingkat tinggi, kesulitan siswa ditunjukkan dari masih rendahnya keterampilan berpikir siswa dalam menyelesaikan soal eksponen dan logaritma. Salah satu penyebab rendahnya keterampilan berpikir siswa adalah kesalahan teknis. Ariani (2014) mengemukakan bahwa alternatif solusinya yaitu mengetahui kesiapan atau kemampuan siswa. Hal ini menunjukkan pentingnya mengetahui kemampuan siswa melalui analisis keterampilan berpikir siswa.

Pentingnya menganalisis keterampilan berpikir siswa khususnya pada keterampilan berpikir tingkat tinggi juga ditunjukkan dari tuntutan kurikulum 2013 yang menjadikan peningkatan HOTS (Higher Order Thinking Skill) sebagai salah satu sasaran pembelajaran dan penilaian. Alasan peningkatan HOTS tersebut yaitu karena berpikir tingkat tinggi dapat mendorong peserta didik untuk berpikir secara luas dan mendalam tentang materi pelajaran (Widana, 2017).

Analisis keterampilan siswa tersebut dapat dilakukan melalui eksplorasi kemampuan mereka dalam memecahkan masalah yang dapat mewakili setiap indikator keterampilan berpikir tingkat tinggi berdasarkan taksonomi Anderson. Oleh karena itu penelitian ini mengkaji tentang analisis keterampilan berpikir tingkat tinggi siswa dalam pemecahan masalah matematika berdasarkan taksonomi Anderson. Tujuan dari penelitian ini adalah untuk mengetahui deskripsi hasil analisis keterampilan berpikir tingkat tinggi siswa dalam pemecahan masalah matematika berdasarkan taksonomi Anderson.

\section{TINJAUAN PUSTAKA}

Hasil penelitian Ariani (2014) menunjukkan bahwa keterampilan berpikir subjek assimilator (siswa bergaya belajar AC dan RO) masih rendah, yaitu tingkat berpikir tertinggi subjek hanya sampai tingkat $\mathrm{C} 2$. Persentasi rata-rata tingkat keterampilan berpikir siswa yaitu $\mathrm{C} 1$ sebesar $100 \%$, C2 sebesar $85.71 \%$, C3 sebesar 33.33\%, C4 sebesar 59.375\%, C5 sebesar 10.71\%, dan C6 sebesar $6.48 \%$. Dari hasil penelitian tersebut terlihat bahwa keterampilan berpikir tingkat tinggi siswa tergolong rendah. Peneliti menemukan beberapa kesalahan siswa, diantaranya kesalahan konsep, kesalahan fakta dan kesalahan teknis. Kesalan fakta yang dilakukan berupa kesalahan dalam menuliskan simbol matematika. Sedangkan kesalahan teknis yang dilakukan berupa kesalahan dalam menentukan prosedur yang tepat dan kesalahan dalam perhitungan. Ariani (2014) menemukan bahwa penyebab kesalahan tersebut terjadi karena subjek kurang dalam pengetahuan konseptual yang merupakan prasyarat untuk dapat mengaplikasikan pengetahuan prosedural. Hal tersebut juga disebabkan dari tidak seringnya siswa latihan pemecahan masalah yang memang memerlukan keterampilan berpikir tingkat tinggi.

Penelitian yang dilakukan Novianti (2014) terhadap 2 orang subjek dengan gaya belajar investigatif, menunjukkan bahwa rata-rata siswa memiliki keterampilan berpikir tingkat tinggi yang tergolong sedang yaitu 50\%. Peneliti menemukan bahwa siswa tipe investigatif pertama berada pada kategori sangat rendah yaitu 30\%, karena siswa tipe investigatif pertama tidak memenuhi 2 indikator kemampuan berpikir tingkat tinggi yaitu mengekreasi dan evaluasi. Sedangkan, siswa tipe investigatif kedua berada pada kategori sedang yaitu 70\%, karena siswa tipe investigatif kedua tidak memenuhi 1 indikator kemampuan berpikir tingkat tinggi yaitu evaluasi. Secara umum kesalahan dan hambatan yang dialami siswa investigatif dalam pemecahan masalah matematika tersebut yaitu: (1) ketidak cermatan dalam berpikir (2) kelemahan dalam menganalisis masalah (3) siswa kurang gigih dalam menemukan solusi. Secara garis besar kesalahan ini disebabkan karena siswa belum terbiasa menghadapi soal-soal dalam bentuk pemcahan masalah yang membutuhkan keterampilan berpikir tingkat tinggi. 


\section{METODE PENELITIAN}

Penelitian ini merupakan jenis penelitian kualitatif dengan metodologi pendekatan deskriptif. Hal yang didekripsikan adalah tingkat keterampilan berpikir tingkat tinggi siswa dalam pemecahan masalah matematika bedasarkan ranah kognitif taksonomi Anderson, yaitu: menganalisis (C4); mengevaluasi (C5); dan mencipta (C6). Pendiskripsian diperoleh melalui pengamatan langsung dalam proses menyelesaikan masalah yaitu menganalisis hasil tes keterampilan berpikir tingkat tinggi siswa dalam memahami masalah, merencanakan penyelesaian, menyelesaikan masalah dan melakukan evaluasi. Deskripsi tersebut juga didukung oleh data hasil wawancara setelah tes dilaksanakan.

Pemilihan subjek penilitian diambil dari kelas XI MIPA SMA Negeri 1 Mamuju menngunakan teknik purposive sampling. Subjek yang dipilih sebanyak 2 orang dengan mempertimbangkan beberapa kriteria, yaitu kemampuan awal yang dimiliki siswa, kemampuan merepresentasikan jawaban, pertimbangan guru mata pelajaran matematika, dan perbedaan kategori.

Kemampuan awal yang dimaksud yaitu, siswa yang memiliki kemampuan matematika tinggi yang dapat ditunjukkan dari nilai akademis tinggi, atau dari keterlibatan siswa dalam mengikuti kegiatan yang membiasakannya dengan aktivitas pemecahan masalah seperti bimbingan OSN. Sedangkan perbedaan kategori yang dimaksud yaitu, 1 subjek mewakili kategori siswa yang mengikuti bimbingan OSN bidang Matematika (S1) dan 1 subjek lainnya mewakili kategori siswa yang tidak mengikuti bimbingan OSN bidang Matematika (S2).

Pengujian keabsahan data menggunakan triangulasi waktu, yang dicapai dengan melakukan pengulangan wawancara untuk mencari kesesuaian data yang bersumber dari masalah yang sama pada waktu yang berbeda. Bila terdapat banyak kesamaan data yang diperoleh melalui triangulasi maka data dinyatakan valid.

\section{HASIL DAN PEMBAHASAN}

Deskripsi hasil analisis keterampilan berpikir tingkat tinggi siswa dalam menyelesaikan masalah matematika yang telah diverifikasi melalui wawancara diringkas dalam Tabel 1.

TABEL 1. Deskripsi Hasil Analisis Keterampilan Berpikir Tingkat Tinggi

Masalah Matematika Deskripsi

Kategori Menganalisis oleh S1

Aljabar: Persamaan Linear Dua Variabel

Menganalisis dengan cara mengidentifikasi

dan mengelompokkan informasi yang

diketahui yang digunakan untuk

menginterpretasi masalah ke dalam model matematika.

Geometri: Dimensi Tiga

Menganalisis dengan cara mengidentifikasi dan membagi informasi yang diketahui yang digunakan untuk menginterpretasi masalah ke dalam bentuk gambar;

Menganalisis dengan cara mengidentifikasi jenis segitiga lalu menentukan panjang sisinya dengan menghubungkannya dengan sisi bangun yang lain. Tetapi terdapat kesalahan hasil analisis, karena kesalahan saat mengidentifikasi. 
Aljabar: Persamaan Linear Dua Variabel

Geometri: Dimensi Tiga
Menganalisis dengan cara menginterpretasi informasi yang diketahui untuk dihubungkan menjadi model matematika. Akan tetapi, model yang terbentuk keliru karena kesalahan dalam menginterpretasi dan menghubungkan informasi.

Menganalisis dengan cara mengidentifikasi dan menginterpretasi informasi yang diketahui ke dalam bentuk gambar, kemudian memisahkan bagian yang ditanyakan menjadi gambar baru untuk memudahkan dalam menentukan panjang sisi. Tetapi terdapat kesalahan hasil analisis, karena kesalahan dalam mengidentifikasi dan memahami.

Kategori Mengevaluasi oleh S1

Aljabar: Persamaan Linear Dua Variabel

Geometri: Dimensi Tiga

Mengevaluasi dengan cara memberikan penilaian terhadap suatu solusi dalam rangka penarikan kesimpulan pemecahan masalah, melalui pengujian model matematika;

Memberi argumentasi tentang kriteria penilaian kebenaran kesimpulan pemecahan masalah yaitu melalui pengujian kembali model matematika;

Menerima pemisalan dari peneliti dengan cara mengkaji maksud dari setiap elemen model matematika;

Menolak persamaan dari peneliti dengan cara mengidentifikasi kesalahannya dan memberikan argumentasi yang mendukung pendapatnya dengan menginterpretasi elemen model matematika kemudian mengenali hubungannya;

Mengevaluasi persamaan awal yang dibentuk berdasarkan dugaan sementara.

Mengevaluasi dengan cara menelusuri kembali cara memperoleh suatu hasil;

Mengevaluasi dengan mengidentifikasi kembali jenis segitiga melalui gambar;

Memberi argumentasi tentang kriteria penilaian kebenaran kesimpulan pemecahan masalah yaitu dengan membandingkan luas melalui gambar.

Kategori Mengevaluasi oleh S2

Aljabar: Persamaan Linear Dua Variabel

Mengevaluasi dengan cara memberikan penilaian terhadap suatu solusi dalam rangka penarikan kesimpulan pemecahan masalah, dengan membandingkan solusi persamaan yang diperoleh. Tetapi kesimpulan yang diambil tidak tepat karena persamaan tidak 


\begin{tabular}{|c|c|}
\hline & tepat; \\
\hline & $\begin{array}{l}\text { Memberi argumentasi tentang kriteria } \\
\text { penilaian kebenaran kesimpulan pemecahan } \\
\text { masalah yaitu dengan mensubstitusi solusi } \\
\text { persamaan ke persamaan; }\end{array}$ \\
\hline & $\begin{array}{l}\text { Menerima pemisalan dari peneliti dengan } \\
\text { menyamakan maksud persamaan peneliti } \\
\text { dengan pemisalan subjek; }\end{array}$ \\
\hline & $\begin{array}{l}\text { Menerima persamaan dari peneliti dengan cara } \\
\text { mengidentifikasi kesalahannya dan } \\
\text { memberikan argumentasi yang mendukung } \\
\text { pendapatnya dengan } \\
\text { hubungannya. }\end{array}$ \\
\hline \multirow[t]{3}{*}{ Geometri: Dimensi Tiga } & $\begin{array}{l}\text { Mengevaluasi dengan cara mengidentifikasi } \\
\text { kembali letak sudut siku-siku melalui gambar. }\end{array}$ \\
\hline & $\begin{array}{l}\text { Tetapi terdapat kesalahan saat } \\
\text { mengidentifikasi; }\end{array}$ \\
\hline & $\begin{array}{l}\text { Memberi argumentasi tentang kriteria } \\
\text { penilaian kebenaran kesimpulan pemecahan } \\
\text { masalah yaitu memprediksi luas dengan } \\
\text { membandingkan luas pada gambar. }\end{array}$ \\
\hline \multicolumn{2}{|l|}{ Kategori Mencipta oleh S1 } \\
\hline \multirow[t]{2}{*}{ Aljabar: Persamaan Linear Dua Variabel } & $\begin{array}{l}\text { Mencipta dengan cara membentuk struktur } \\
\text { baru berupa persamaan sederhana melalui } \\
\text { kemampuan analisis dan penerapan, yang } \\
\text { berguna untuk menjawab pertanyaan masalah; }\end{array}$ \\
\hline & $\begin{array}{l}\text { Merancang suatu cara untuk menyelesaikan } \\
\text { masalah dengan cara menerapkan berbagai } \\
\text { metode kemudian menilai efektivitasnya. }\end{array}$ \\
\hline \multirow[t]{2}{*}{ Geometri: Dimensi Tiga } & $\begin{array}{l}\text { Mencipta dengan merancang suatu cara sendiri } \\
\text { untuk menyelesaikan masalah dalam } \\
\text { menentukan sisi segitiga; }\end{array}$ \\
\hline & $\begin{array}{l}\text { Mencipta dengan cara membentuk struktur } \\
\text { baru berupa perbandingan sebagai kesimpulan } \\
\text { penyelesaian masalah. Tetapi kesimpulan yang } \\
\text { diambil tidak tepat karena kesalahan } \\
\text { mengidentifikasi jenis segitiga. }\end{array}$ \\
\hline \multicolumn{2}{|l|}{ Kategori Mencipta oleh S2 } \\
\hline Aljabar: Persamaan Linear Dua Variabel & $\begin{array}{l}\text { Tidak mampu mencipta, karena tidak dapat } \\
\text { menggunakan cara baru yang tepat dalam } \\
\text { menyelesaikan masalah. }\end{array}$ \\
\hline Geometri: Dimensi Tiga & $\begin{array}{l}\text { Tidak mampu mencipta, karena tidak dapat } \\
\text { menemukan struktur membentuk struktur baru } \\
\text { dalam menjawab masalah, dan tidak } \\
\text { menggunakan cara baru yang tepat dalam } \\
\text { menyelesaikan masalah. }\end{array}$ \\
\hline
\end{tabular}




\section{PEMBAHASAN}

Berdasarkan hasil analisis keterampilan berpikir tingkat tinggi siswa dalam menyelesaikan masalah matematika terlihat bahwa kedua subjek dapat menggunakan keterampilannya meskipun tidak tercapai secara maksimal yang ditunjukkan dari tidak berhasilnya siswa menemukan jawaban yang tepat. Kedua subjek dalam pemecahan masalah tingkat tinggi melibatkan hampir seluruh aspek keterampilan berpikir berdasarkan taksonomi Anderson, baik secara langsung ataupun untuk menjembatani subjek dalam mengkonstruksi keterampilan berpikir tingkat tinggi.

Hasil analisis juga menunjukkan perbedaan keterampilan berpikir tingkat tinggi siswa dari setiap kategori, yaitu kategori siswa yang mengikuti bimbingan OSN bidang Matematika (subjek pertama) dan siswa yang tidak mengikuti bimbingan OSN bidang Matematika (subjek kedua). Hal tersebut dapat disebabkan karena perbedaan kemampuan awal dari siswa. Sebagaimana dikatakan oleh Corelina (2000) bahwa keterampilan berpikir tingkat tinggi dan hasil belajar kognitif berkaitan dengan kemampuan awal siswa yang terbentuk melalui pengalaman pembelajaran siswa (Kawuwung, 2011)

Dalam menganalisis S1 betul-betul memahami maksud setiap komponen yang terbentuk pada saat pemecahan masalah aljabar. S1 mampu membentuk model matematika yang tepat dan memahami maksud dari setiap elemen pada model matematika yang dibentuk. Sedangkan S2 mengalami kesalahan saat menyelesaikan masalah aljabar, sehingga model matematika yang dibentuk tidak tepat. Hal tersebut karena S2 langsung menerapkan pengalamannya, yaitu membentuk dua persamaan kemudian menggunakan metode eliminasi dan substitusi untuk menyelesaikannya.

Dalam mengevaluasi S1 melibatkan keterampilan berpikir tingkat tingginya mulai pada tahap merencanakan penyelesaiannya, pada tahap perencanaan S1 memiliki hipotesis bahwa penyelesaiannya menggunakan metode eliminasi dan substitusi. Namun, setelah melakukan evaluasi S1 menyadari kesalahan dari penyelesaian yang diperoleh, sehingga S1 mencoba berbagai cara untuk menentukan langkah penyelesaian yang tepat. Selain itu, dalam mengevaluasi pada indikator menerima atau menolak pernyataan dari peneliti, S1 selalu melibatkan kemampuan analisisnya dengan mengenali dan menjelaskan maksud setiap elemen dan hubungannya.

Sedangkan, keterampilan mengevaluasi S2 tidak diterapkan setelah selesai melaksanakan langkah penyelesaian, sehingga S2 tidak menyadari kesalahannya dalam membentuk persamaan. Akan tetapi S2 baru menyadarinya ketika diperlihatkan persamaan yang benar. Hal ini menunjukkan S2 bagus dalam melakukan evaluasi untuk indikator menerima pernyataan, dengan kata lain S2 mampu mengenali jawaban yang benar dan yang salah jika diperlihatkan jawaban yang benar.

Dalam mencipta, S1 menerapkan pengalaman yang didapatkannya sejak SMP untuk menyelesaikan masalah aljabar dan pengalaman belajar pada saat pra OSN untuk menyelesaikan masalah geometri. Sedangkan, S2 tidak mampu mencipta karena pengalamannya dalam mengerjakan masalah aljabar khususnya pokok bahasan sistem persamaan linear dua variabel yaitu objek yang diketahui dan yang ditanyakan selalu diinterpretasi dalam bentuk sistem persamaan yang terdiri dari dua persamaan, kemudian nilai yang tidak diketahui ditentukan menggunakan metode eliminasi dan substitusi. Dan pengalaman tersebut langsung diterapkan dalam proses pemecahan masalah. Sedangkan pada masalah geometri, pengalaman S2 hanya mengerjakan soal yang tergolong mudah dalam menentukan sisinya, sehingga S2 tidak dapat memecahkan masalah geometri dengan baik dan tepat.

Berdasarkan uraian mengenai keterampilan berpikir tingkat tinggi siswa dalam mencipta, terlihat bahwa pengalaman belajar yang diperoleh siswa sangat berpengaruh dalam peningkatan potensi yang dimilki oleh setiap siswa. Hal ini disebabkan karena perbedaan pengalaman belajar siswa, yaitu siswa yang mengikuti bimbingan OSN bidang Matematika tentunya akan 
mendapatkan pengalaman belajar yang lebih banyak dari siswa yang tidak mengikuti bimbingan berkaitan dengan pemecahan masalah maematika. Hal tersebut didukung oleh pendapat Dimyanti \& Mudjiono (2006) yang menyatakan bahwa aktivitas belajar adalah pembentukan hubungan antara stimulus dan respons, dan pengulangan terhadap pengalaman-pengalaman yang berdampak pada besarnya peluang untuk menghasilkan respon benar. Artinya pengalaman belajar dari siswa dalam pemecahan masalah matematika yang menentukan keberhasilan siswa tersebut dalam merespon dengan baik hingga memperoleh pemecahan masalah yang baik dan tepat.

Secara logis dapat dikatakan bahwa keikutsertaan subjek dalam bimbingan OSN bidang Matematika memiliki pengaruh terhadap cara berpikir tingkat tingginya. Hal tersebut karena siswa dibiasakan dengan soal-soal dengan level berpikir tingkat tinggi, sehingga tercapai perkembangan keterampilan berpikir tingkat tinggi yang optimal, yang ditunjukkan dari prosedur berpikir tingkat tingginya yang berjalan secara terstruktur dan dapat memperoleh hasil yang tepat. Hal ini sejalan dengan pendapat Hendrono (1978) bahwa bimbingan merupakan proses pemberian bantuan yang terus menerus dan sistematis dari pembimbing kepada terbimbing agar tercapai pemahaman, penerimaan, pengarahan, serta perwujudan diri dalam mencapai tingkat perkembangan yang optimal (Marlise, dkk, 2011). Sehingga, adanya bimbingan memberikan pengaruh terhadap perkembangan potensi siswa, dalam hal ini keterampilan berpikir tingkat tinggi dalam pemecahan masalah matematika.

\section{KESIMPULAN}

Berdasarkan hasil penelitian dan pembahasan, maka kesimpulan dalam penelitian ini yaitu sebagai berikut.

1. Keterampilan berpikir tingkat tinggi S1 (siswa yang mengikuti bimbingan OSN bidang Matematika) dalam pemecahan masalah matematika berdasarkan taksonomi Anderson, yaitu:

- Dalam kategori menganalisis, siswa selalu melibatkan informasi yang diketahui dan yang ditanyakan, kemudian membuat representasi model matematika aljabar maupun geometri. Akan tetapi pada masalah geometri siswa tidak mendapatkan hasil analisis yang tepat karena kesalahan dalam mengidentifikasi jenis segitiga pada hasil representasi model matematika geometri.

- Dalam kategori mengevaluasi, siswa melibatkan kemampuan menganalisisnya dengan mengurai suatu objek untuk dipahami maknanya, kemudian memutuskan kebenaran objek tersebut.

- Dalam kategori mencipta, siswa selalu membentuk struktur baru sebagai acuan dalam pengambilan keputusan penyelesaian masalah. Akan tetapi, pada masalah geometri kesimpulan yang diambil tidak tepat karena kesalahan yang bermula dari kesalahan dalam mengidentifikasi jenis segitiga. Namun, terdapat keterampilan mencipta yang menonjol pada masalah geometri, yaitu dalam menggunakan cara baru dan berbeda untuk menentukan panjang sisi suatu bangun datar

2. Keterampilan berpikir tingkat tinggi S2 (siswa yang tidak mengikuti bimbingan OSN bidang Matematika) dalam pemecahan masalah berdasarkan taksonomi Anderson, yaitu:

- Dalam kategori menganalisis pada masalah aljabar siswa langsung menerapkan ingatannya berupa penyelesaian masalah dengan membentuk dua persamaan, kemudian diselesaikan menggunakan metode eliminasi dan substitusi, selain itu siswa juga salah memahami hubungan sisi suatu segitiga. Sedangkan pada masalah geometri siswa tidak mampu mengenalisis dengan tepat jenis segitiga yang terdapat dalam kubus jika terdapat sisi dari diagonal kubus. 
- Dalam kategori mengevaluasi, siswa dapat memperoleh hasil yang tepat jika diperlihatkan jawaban yang benar, seperti pada saat diperlihatkan pemisalan dan persamaan yang benar pada masalah aljabar.

- Dalam kategori mencipta, kemampuan siswa tidak dapat didentifikasi.

\section{DAFTAR PUSTAKA}

Abosalem, Y. (2016). Assessment Techniques and Students' Higher-Order Thinking Skills. International Journal of Secondary Education. 4 (1), 1-11.

Anderson, L. W., \& Krathwohl, D. R.. (2001). A Taxonomy for Learning, Teaching, and Assessing. New York: Longman.

Anjarsari, P. (2014). Pentingnya Melatih Keterampilan Berpikir (Thinking Skills) dalam Pembelajaran IPA SMP. Makalah. Presented in PPM "Optimalisasi Implementasi Kurikulum 2013 dengan Workshop Pengembangan LKS IPA Berpendekatan GuidedInquiry untuk Mengembangkan Thinking Skills dan Sikap Ilmiah Siswa" organized by Pendidikan IPA, FMIPA Universitas Negeri Yogyakarta.

Apino, E., \& Retnawati, H. (2017). Developing Instructional Design to Improve Mathematical Higher Order Thinking Skills of Students. Journal of Physics: Conference Series, 812 (1).

Ardiana, Meiriza, \& Sudarmin. (2015). Penerapan Self Assesment untuk Analisis Keterampilan Berpikir Tingkat Tinggi Siswa. Jurnal Inovasi Pendidikan Kimia, 9 (1), 1459-1467.

Ariani, E. (2014). Analisis Keterampilan Berpikir berdasarkan Taksonomi Anderson pada Siswa Gaya Belajar Assimilator dalam Menyelesaikan Soal Eksponen dan Logaritma Kelas X Sma Negeri 3 Kota Jambi. Skripsi. Universitas Jambi, Jambi.

Dimyanti \& Mudjiono. 2006. Belajar dan Pembelajaran. Jakarta: Rineka Cipta.

Kawuwung, F. (2011). Profil Guru, Pemahaman Kooperatif NHT, dan Kemampuan Berpikir Tingkat Tinggi di SMP Kabupaten Minahasa Utara. Jurnal El-Hayah, 1 (4), 157-166.

Novianti, D. (2014). Analisis Kemampuan Berpikir Tingkat Tinggi Siswa Dengan Gaya Belajar Tipe Investigatif Dalam Pemecahan Masalah Matematika Kelas Vii Di Smp N 10 Kota Jambi. Skripsi. Universitas Jambi, Jambi.

Rofiah, E., Aminah, N. S., \& Ekawati, E. Y. (2013). Penyusunan Instrumen Tes Kemampuan Berpikir Tingkat Tinggi Fisika pada Siswa SMP. Jurnal Pendidikan Fisika, 1 (2), 1722.

Soemarjadi, Muzni, R., \& Wikdati, Z. (1991). Pendidikan Keterampilan. Jakarta: Depdikbud.

Swartz, R., \& McGuiness, C. (2014). Developing and Assessing Thinking Skills. Final Report of Thinking Skills Project. Boston \& Northern Ireland: The International Baccalaureate Organisation.

Widana, I Wayan. 2017. Modul Penyusunan Soal HOTS. Jakarta: Direktorat Pembinaan SMA, Direktorat Jenderal Pendidikan Dasar dan Menengah, Departemen Pendidikan da Kebudayaan.

Widati, S., Asmuni, Effeni, \& Marlise. (2011). Bimbingan Belajar Bahasa Inggris KKN untuk Anak-anak Desa Padang Palangeh Kec. Pelepat Lilir Kab. Bungo. Makalah. Universitas Muara Bungo. 